\title{
KAJIAN PRAGMATIK \\ PADA DAKWAH USTAZ MUHAMMAD NUR MAULANA
}

\author{
Ninda Adriani, Itaristanti, dan Indrya Mulyaningsih \\ IAIN Syekh Nurjati Cirebon \\ Alamat pos-el: nindaadriani98@gmail.com \\ salsabilamashel86@gmail.com \\ indrya.m@gmail.com
}

ABSTRAK

ABSTRACT
Bahasa yang digunakan dalam berdakwah sangat menarik untuk dibahas dalam sebuah penelitian, maka dari itu judul dalam penelitian ini yakni kajian pragmatik dalam dakwah Ustaz Muhammad Nur Maulana. Penelitian ini bertujuan untuk mendeskripsikan tindak tutur pada dakwah Ustaz Muhammad Nur Maulana yakni tindak tutur lokusi, ilokusi, dan perlokusi dikaji secara pragmatik. Sumber data penelitian ini adalah youtube dan acara televisi Islam Itu Indah. Metode, dalam penelitian metode kualitatif deskripsi pengumpulan data dengan teknik rekam, catat, dan dokumentasi. Keabsahan data, yang digunakan Bahan referensi yakni adanya pendukung untuk membuktikan data yang telah ditemukan oleh penulis. Teknik analisis yang digunakan metode padan ekstra lingual. Hasil penelitian, yang didapatkan tindak tutur lokusi, ilokusi, dan perlokusi. Jenis lokusi, yang didapatkan bertanya, dan menginformasikan, jenis ilokusi didapatkan asertif, direktif, ekspresif, komisif, deklaratif, jenis perlokusi, yang didapatkan melakukan sesuatu.

Kata Kunci: tindak tutur lokusi, ilokusi, perlokusi, Ustaz Muhammad Nur Maulana, youtube, acara Islam Itu Indah

The language used in da'wah is very interesting to be discussed in a study, therefore the title in this research is the pragmatic study in the propagation of Ustaz Muhammad Nur Maulana. This study aims to describe the speech acts of Ustaz Muhammad Nur Maulana, namely locution, illocutionary acts, And perlocutionary speech are studied pragmatically. The data source In This study is youtube And the television program Islam Itu Indah. The method used In the qualification of qualitative methods is description of data collection using record, notes, And documentation techniques. The validity of the data used In the research triangulation are researchers, methods, theories, And data source. The analysis techniques used is the extralingual equivalent method. The results of the study obtained speech acts of locution, illocution, And perlocutionary. The type of locution obtained asks And informs, the type of illocution obtained is assertive, directive, expressive, commissive, declarative, the type of percussion obtained by doing something.

Keywords: locus speech acts, illocution, perlokusi, Ustaz Muhammad 
PENDAHULUAN Bahasa merupakan alat interaksi sosial atau alat komunikasi. Kepribadian seseorang dapat dilihat yakni dari bahasa yang disampaikan pada saat argumen, dan menyampaikan pendapat. Lewat berbicara maka seseorang sedang mengekspresikan yang dituturkan melalui bahasa yang digunakan oleh penutur. Bahasa merupakan suatu tanda yang membentuk budaya manusia. Dakwah merupakan bentuk aktivitas seseorang dalam menyampaikan pesan agama suatu nasihat atau ilmu di depan banyak orang. Orang yang berdakwah harus memiliki kemampuan dalam berbahasa karena pendakwah harus memengaruhi atau mengajak pendengar agar penyampaian isi dakwah dapat diterima oleh pendengar, dan diikuti oleh pendengar. Apabila pendengar mampu mengubah cara berpikir dan melaksanakan yang disampaikan oleh pendakwah tersebut dikatakan berhasil dakwahnya. Pendakwah dikatakan belum berhasil jika pesan tidak diterima dengan baik oleh pendengar.

Berdakwah sebenarnya ingin menyampaikan sebuah isi pesan lewat cara pendakwah berbicara, dan mimik. Komunikasi dalam konteks tertentu memiliki pesan yang ingin disampaikan kepada pendengar baik pesan yang terkandung. Gaya penyampaian dakwah seorang berbedabeda. Pendakwah biasa disebut dengan dai. Negara Indonesia dikenal dengan banyaknya Ustaz/Ustazah, Kiai/Nyai diantaranya; Ustaz Danu, Mamah Dedeh, Ustaz Yusuf Mansyur, Ustazah Oki Setiana Dewi, Ustaz Maulana, Ustaz Abdul Somad. Bahasa yang digunakan dalam berdakwah sangat menarik untuk dibahas dalam sebuah penelitian, maka dari itu judul dalam penelitian ini yakni kajian pragmatik dalam dakwah Ustaz Muhammad Nur Maulana. Pembahasan ini berfokus pada tindak tutur lokusi, ilokusi, dan perlokusi. Ustaz Muhammad Nur Maulana seorang penceramah, pendakwah mulai dikenal oleh masyarakat Indonesia pada tahun 2010 lewat acara televisi Islam Itu Indah, sebelum dikenal oleh masyarakat luas Ustaz Muhammad Nur Maulana merupakan seorang pendakwah daerah. Keahliannya dalam membawakan suatu materi ceramah dengan ragam bahasa, dan gaya bahasa yang berbeda-beda membuat Ustaz Muhammad Nur Maulana dikenal, dan disukai oleh banyak masyarakat. Dakwah yang disampaikan oleh Ustaz Muhammad Nur Maulana sudah memiliki kebaruan tersendiri tidak dibuat-buat atau biasa disebut dengan uniksel youtube. (2016 Maret 12). Diakses pada tanggal:

Oktober

2019[Berkasvidio].Diaksesdarihttps://www.vidioder.com/media? $\operatorname{mode}=2$ \&url=https://www.youtube.com/watch? $\mathrm{v}=\mathrm{L}-184 \mathrm{qG} 3 \mathrm{hLw}$. Dunia dakwah tentunya Masyarakat ada yang tidak menyukai dakwah Ustaz Muhammad Nur Maulana menganggapnya dakwah yang disampaikan terlalu berlebihan dalam menyampaikan dakwah, akan tetapi Ustaz Muhammad Nur Maulana memiliki ciri khas tersendiri dalam menyampaikan pesan dakwah yakni "Jemaah Oo jemaah Alhamdulillah" ketika ingin memulai ceramahnya. Pembawaan yang sangat santai, dan tidak membosankan maka pesan yang ingin disampaikan dapat diterima dengan baik.

Alasan mendasar yang menjadi tolak ukur untuk melakukan penelitian ini bahasa. Bahasa merupakan alat untuk seseorang menyampaikan informasi, di dalam penggunaan bahasa terdapat spesifikasi mengenai tindak tutur. Tindak tutur yang digunakan oleh setiap individu berbeda, 
memiliki cara tersendiri dalam menyampaikan informasi, sama halnya dengan pendakwah saat menyampaikan informasi kepada pendengar sangat beragam, maka dari itu penulis tertarik untuk melakukan penelitian pada dakwah yang disampaikan oleh Ustaz Muhammad Nur Maulana, karena bahasa yang gunakan saat berdakwah Ustaz Muhammad Nur Maulana sangat beragam diantaranya; memakai bahasa daerah, bahasa santai, dan memakai bahasa Indonesia. Bahasa yang dipakai sangat berkaitan sesuai materi yang akan dibahas jika materi mengenai remaja Ustaz Muhammad Nur Maulana menggunakan bahasa santai, dan sebagainya. Maka dari itu penulis tertarik ingin mengetahui tindak tutur dalam dakwah Ustaz Muhammad Nur Maulana. Tindak tutur Ustaz Muhammad Nur Maulana dalam dakwah pada acara televisi Islam Itu Indah berilah nama seorang anak dengan baik, dan bagus bermaksudkan untuk memberikan nama kepada setiap anak yang baru lahir karena jangan sampai anak itu merasa malu dengan namanya sendiri. Dalam dakwah tersebut Ustaz Muhammad Nur Maulana memberikan contoh jangan memberikan nama Izroil karena memang namanya bagus diperoleh dari bahasa Arab akan tetapi makna atau arti dari nama itu adalah malaikat pencabut nyawa. Seseorang dapat dikenal dari nama, maka berikan nama kepada anak-anak dengan nama dan makna yang bagus.

Berdasarkan latar belakang di atas, masalah-masalah yang akan diteliti dapat dirumuskan sebagai berikut. Bagaimana bentuk tindak tutur dalam dakwah Ustaz Muhammad Nur Maulana? bagaimana makna tindak tutur dalam dakwah Ustaz Muhamad Nur Maulana? tujuan penulisan di atas memiliki tujuan penulisan sebagai berikut. Mendeskripsikan bentuk tuturan dakwah Ustaz Muhammad Nur Maulana, dan Mendeskripsikan makna tuturan dakwah Ustaz Muhammad Nur Maulana. Dakwah dari segi bahasa artinya panggilan, seruan, atau ajakan. Orang yang berdakwah disebut dengan $D a{ }^{\prime} i$, dan orang yang menerima dakwah atau orang yang didakwahi disebut dengan mad'u. (Muhammad \& Wahyu, 2006: 15), ilmu dakwah dapat dikategorikan sebagai disiplin ilmu karena sudah mencangkup beberapa hal sebagai berikut; mempunyai akar sejarah yang jelas adalah pendakwah itu harus memiliki nasab atau keturunan yang jelas sampai kepada baginda Nabi Muhammad SAW. Tidak semua orang bisa berdakwah, dan diterima baik dengan orang lain. Orang yang berdakwah harus memiliki pandangan sejarah, yang jelas; tokoh-tokoh ahli ilmu dakwah yang dikenal, dan tekun untuk mengembangkannya yakni adanya guru-guru atau tokoh-tokoh ahli agama yang berkompeten dalam mempelajari ilmu agama, dan tekun dalam mengembangkan ilmu agama karena semakin canggih alat komunikasi maka semakin cepat menerima informasi yang ingin disampaikan; masyarakat akademis yang senantiasa mempelajari, dan mengembangkan ilmu dakwah selain tokohtokoh ahli agama juga adanya masyarakat yang ingin mengembangkan ilmu agama, dan berkembang ingin mempelajari ilmu agama, dan dakwah; diakui oleh lembaga yang mengkaji tentang berbagai disiplin ilmu, selain itu juga ilmu dakwah, dan orang yang berdakwah adanya lembaga yang mengkaji mengenai ilmu yang disampaikan oleh pendakwah apakah sudah selaras dengan syariat Islam atau keluar dari ajaran agama Islam; orang yang meneliti cukup intens mengenai teoriteori berdakwah adanya seorang ilmuwan yang mengkaji perkembangan agama, dan teori-teori yang terkait dalam mengkaji ilmu agama tersebut. 
Adanya perubahan hukum atau aturan dalam agama, dan sebagainya.

Pragmatik adalah suatu cabang ilmu bahasa yang semakin dikenal pada masa sekarang ini. Pragmatik adalah cabang ilmu bahasa yang mempelajari struktur bahasa secara eksternal. Pragmatik yakni membahas mengenai struktur bahasa secara eksternal, yakni kebahasaan itu digunakan dalam berkomunikasi. Pragmatik sebagai cabang ilmu bahasa yang mengkaji ilmu bahasa yang terdiri dari; fonologi, morfologi, sintaksis, dan semantik dari segi eksternal (Wijana, 1996: 1). Pragmatik adalah ilmu yang membahas mengenai hubungan antara bentuk-bentuk linguistik, dan pemakai bentuk itu sendiri. Studi pragmatik melibatkan penafsiran tentang yang dimaksudkan orang di dalam suatu konteks khusus, dan konteks itu berpengaruh terhadap yang dikatakan (Mahu, 2018). pragmatik merupakan cabang-cabang ilmu bahasa yang menelaah makna-makna satuan lingual, yakni mengkaji makna secara eksternal atau mengkaji makna bahasa dari luar bahasa tersebut (Ibrahim, 1993: 11). Pragmatik adalah studi yang membahas mengenai makna-makna yang mengkaji ungkapan linguistik dalam konteks, dan bentuk tuturan yang diutarakan. Penggunaan pragmatik sangat erat kaitannya dengan penggunaan bahasa secara fungsional. Pragmatik mengkaji mengenai struktur bahasa secara eksternal atau berasal dari luar makna yang disampaikan. Ilmu pragmatik banyak berhubungan dengan analisis makna yang bersifat dari luar konteks tuturan.

(Wijana, 2013: 11), sehubungan dengan bermacam-macam maksud, dan tujuan tuturan yang dikomunikasikan, terdapat sejumlah aspek yang di dalamnya. Penutur, dan lawan tutur, penutur adalah orang yang menyapa sedangkan mitra tutur adalah orang yang diajak untuk bertutur kata dengan penutur. Aspek-aspek yang berkaitan dengan penutur, dan lawan tutur ini adalah usia, latar belakang, sosial ekonomi, jenis kelamin, tingkat keakraban. Konteks tuturan adalah konteks dalam semua aspek fisik maupun aspek nonfisik yang relevan dari tuturan yang bersangkutan. Di dalam ilmu pragmatik mengkaji semua konteks tuturan yang bersangkutan dengan semua latar belakang tuturan tersebut.

Menurut Chaer (dalam Rahmadi, 2009: 20), menjelaskan jika peristiwa tutur (speech Evert) merupakan gejala sosial. Terdapat interaksi antara penutur dalam situasi, dan tempat tertentu. Tindak tutur (speech acts) lebih cenderung sebagai gejala individual, bersifat psikologis, dan ditentukan oleh kemampuan bahasa. Penutur dalam menghadapi situasi tertentu. Tindak tutur merupakan bentuk (Tarigan, 2009: 15) menjelaskan bahwa dalam tindak tutur dibagi ke dalam tiga jenis antara lain. Tindak lokusi yakni berkaitan dengan produksi ujaran yang bermakna. Konsep lokusi sendiri yakni konsep yang berkaitan dengan proposisi kalimat (Pusparini, 2016). pandangan tindak tutur lokusi sebagai satu satuan yang terdiri dua unsur, yakni subyek atau topik (Wijana, 1996: 18). Tindak lokusi adalah melakukan sesuatu tindakan untuk mengatakan sesuatu maksudnya. Contoh ikan paus adalah binatang menyusui, b) jari tangan jumlahnya lima. Dari kalimat a) dan b) diutarakan semata-mata hanya untuk menginformasikan sesuatu tanpa tendensi untuk melakukan sesuatu, apalagi untuk memengaruhi lawan tuturnya, hanya untuk menarik perhatian pendengar. Pembicara menyatakan kepada penyimak bahwa 
$\mathrm{X}$ adalah suatu kata tertentu yang diucapkan dengan persamaan, makna, dan acuan (Surastina, 2018: 179). Tindak ilokusi yakni berkaitan dengan intensitas atau maksud pembicara. Tindak ilokusi apa yang penutur hendak maksudkan dengan ujarannya (Surastina, 2018: 179). Tindak ilokusi adalah tindak tutur yang memengaruhi lawan untuk melakukan suatu tindakan atas apa yang dibicarakan oleh penutur, dengan kata lain tuturan ilokusi adalah tuturan yang mengingat penuturnya atas kebenaran yang diucapkan (Wijana, 1996: 11).

Tindak perlokusi adalah melakukan sesuatu tindakan dengan meyakini sesuatu maksudnya adalah pembicara mengatakan A tetapi pembicara meyakini pendengar untuk melakukan B. Tindak tutur perlokusi yakni berkaitan dengan efek pemahaman pendengar terhadap maksud pembicara yang terwujud dalam tindakan (Surastina, 2018: 179). Tindak tutur yang memberikan tindak untuk memengaruhi pendengar seperti melakukan, mengintimidasi, membujuk, dan sebagainya (Pusparini, 2016). (Prasetyo, 2018), pada klasifikasi tindak tutur dibagi ke dalam lima jenis fungsi umum yang ditunjukkan oleh tindak tutur yakni tindak tutur deklarasi, representatif, ekspresif, direktif, dan komisif. Deklarasi adalah tindak tutur yang dapat mengubah dunia dengan tuturan. Contoh: sekarang Nia menyebutnya sebagai suami istri. Representatif adalah tindak tutur yang menyatakan sesuatu yang diyakini oleh penutur suatu kasus atau bukan Contoh: bumi itu datar yakni menggunakan sebuah representatif, penutur menyamakan kata-kata atau kalimat dengan yang orang tersebut percayai. Ekspresif adalah suatu tindak tutur yang sedang dirasakan oleh penutur contoh: sungguh Sita meminta maaf berarti tuturan tersebut berisikan perasaan bersalah untuk meminta maaf. Direktif adalah tindak tutur yang menyatakan tuturan untuk menyuruh orang lain melakukan sesuatu tindak tutur ini meliputi: perintah, pemesanan, permohonan, pemberian saran seperti yang digambarkan di bawah ini contoh: sungguh Aisyah meminta maaf. Komisif adalah tindak tutur yang menyatakan untuk mengingatkan penutur untuk tindakan-tindakan di masa yang akan datang Contohnya: Ainia akan kembali.

Dalam kajian tindak tutur (speech act) dikenal dengan adanya makna ilokusi, makna lokusi, dan makna perlokusi. Dalam makna lokusi dijelaskan bahwasanya makna tersebut seperti yang dinyatakan dalam ujaran makna secara harfiah, atau makna apa adanya. Makna ilokusi yakni makna yang dipahami oleh pendengar. Makna perlokusi yakni makna yang sesuai dengan yang diinginkan oleh penutur (Chaer, 2013: 70). Dalam kajian tindak tutur, sebuah ujaran sekaligus dapat bermakna lokusi, ilokusi, dan perlokusi. Contoh:" Sapu di mana" pada kalimat sapu di mana jika dikaji secara lokusi hanya keingin tahuan di mana letak sapu tersebut, jika dikaji secara ilokusi ibu bertanya kepada anaknya bahwa sapu di mana? dan jika dikaji secara perlokusi maka artinya ibu itu menyuruh anaknya untuk membersihkan rumahnya.

Kajian oleh (Salafah, n.d, 2015), bahwasanya pada kajian yang dilakukan oleh Salafah ini memiliki kesamaan dengan penulis, yakni pada kajian tindak tutur. Kajian yang dilakukan oleh Salafah yakni tindak tutur dalam ceramah agama KH. A'AD Ainurrusalam, 
sedangkan pada penulisan yang penulis angkat yakni kajian pragmatik pada dakwah Ustaz Muhammad Nur Maulana, adapun metode, yang diambil oleh Salafah sama seperti, yang dilakukan oleh penulis yakni menggunakan metode kualitatif, akan tetapi sumber pengambilan data yang dilakukan oleh Salafah berupa observasi secara langsung, dan ikut serta dalam penelitian yang dilakukan. Berbeda dengan yang dilakukan oleh penulis yakni pengambilan data secara tidak langsung, dan tidak ikut terlibat dalam sumber data tersebut. Sumber data yang penulis gunakan yakni menggunakan akun youtube Islam Itu Indah.

METODE

Metode penelitian kualitatif yakni metode penelitian, yang berlandaskan pada filsafat postpositivisme, yakni berfungsi untuk melakukan penelitian pada kondisi objek yang alamiah. Penelitian kualitatif yang menjadi instrumen utama yakni peneliti itu sendiri berfungsi sebagai kunci, pengambilan sampel, pengambilan data, yakni dilakukan secara purposive, dan snawbaal, pada penelitian kualitatif lebih menekankan makna dari pada generalisasi (Sugiyono, 2015: 15).

Teknik pengumpulan data untuk memperoleh data penulis yakni menggunakan teknik simak, dokumen, rekam dan catat. Teknik simak yakni teknik yang digunakan pada saat penulis menyimak bahasa yang sedang digunakan oleh Ustaz Muhammad Nur Maulana. Pada praktik, yakni peneliti tidak terlibat ke dalam proses komunikasi, maka dari itu teknik yang digunakan dalam penelitian ini yakni teknik simak bebas libat cakap (Sudaryanto, 1993: 134). Jadi dalam hal ini peneliti tidak terlibat dalam tuturan tersebut. Hanya mengamati dan menyimak tuturan bahasa yang disampaikan oleh Ustaz Muhammad Nur Maulana ketika menyampaikan dakwahnya. Teknik pengambilan data yang digunakan yakni teknik purpose sampling, dari rincian data dalam pembahasan tersebut penulis hanya mengambil sampel, yakni dengan cara $\frac{30}{100} \times 227$ data $=68.1$ data. Penulis membulatkan data yang diperoleh Secara keseluruhan dari data lokusi, ilokusi, dan perlokusi sebanyak 65. Data tersebut merupakan rincian pengambilan sampel untuk data analisis. Alasan penulis mengambil $30 \%$ pada penentuan ukuran jumlah sampel, karena; jumlah tindak tutur sebanyak 227 tidak mungkin diambil semua menjadi sampel, agar semua bentuk tindak tutur terwakili menjadi sampel. Berikut data analisis bentuk tindak tutur dan makna yang disampaikan oleh Ustaz Muhammad Nur Maulana.

Teknik analisis data, yang digunakan dalam penulisan ini berupa metode padan extralingual. Metode padan extralingual merupakan metode, yang digunakan untuk menganalisis unsur yang bersifat extralingual atau dari luar bahasa tersebut. Metode pada extralingual yakni menghubungkan masalah bahasa dengan hal yang berada di luar bahasa tersebut. Sebagai metode yang secara konseptual bersifat abstrak, maka agar dapat teroperasional diperlukan langkah-langkah yang konkret yang disebut dengan teknik (Mahsun, 2017: 123). Teknik simak bebas libat cakap merupakan teknik yang digunakan dalam suatu penelitian bahasa di mana penulis tidak terlibat langsung ke dalam 
percakapan yang dilakukan oleh objek dalam penelitian, penulis hanya melihat, dan memantau yang dijadikan dalam objek. Bahasa dalam ceramah yang digunakan oleh Ustaz Maulana dalam dakwahnya pada acara televisi Islam Itu Indah dianalisis menggunakan analisis simak bebas libat cakap untuk mengetahui tindak tutur maksud, dan tujuan yang disampaikan oleh Ustad Muhammad Nur Maulana dari aspek kebahasaan, tetapi juga dikaitkan dengan konteks, dan tujuan tertentu yang terdapat dalam bahasa. Analisis tindak tutur dianggap sangat penting karena ketika seseorang berbicara hal pertama yang harus dipahami adalah maksud dari perkataan seseorang tersebut. Teknik yang digunakan yakni teknik Pilah Unsur Penentu (PUP). Alat yang digunakan yakni daya pilah yang bersifat mental yang dimiliki oleh peneliti sendiri, yakni sesuai dengan penentu yang dipisahkan atau dibagi menjadi berbagai unsur itu maka daya pilah yang dipakai yakni pragmatik. Selanjutnya data yang terkumpul dikelompokkan dalam kartu data untuk ditentukan berdasarkan kriteria yang telah ditetapkan. Berikut kriteria jenis tindak tutur menurut (Banondari, 2015).

\section{PEMBAHASAN}

\section{Bentuk Tindak Tutur dalam Dakwah Ustaz Muhammad Nur Maulana}

a. Tindak tutur lokusi

Tindak tutur lokusi adalah tindak tutur, yang menyatakan sesuatu, dan konsep, yang berkaitan dengan proposisi kalimat. Dalam tindak tutur lokusi terdapat dua jenis, yakni berita, tanya (Ibrahim abd. syukur, 1993: 11).

(1) Tadi kita sudah mendengarkan tausiah dari Ustaz Maulana, sekarang kita kasih kesempatan kepada penonton, yang sudah curhat melalui email kita.

(Data 033.2.00239)

Data 033.2.00239 termasuk ke dalam tindak tutur lokusi pada jenis berita yakni ditandai dengan sebuah informasi pada kalimat " sekarang kita kasih kesempatan kepada penonton, yang sudah curhat melalui email kita" itu termasuk ke dalam tindak tutur lokusi dengan jenis tindak tutur berita. Karena hal tersebut sesuai dengan, yang disampaikan, dan ditayangkan pada saat acara televisi Islam Itu Indah tersebut berlangsung. Tuturan tersebut yakni tidak memerlukan jawaban atas tuturan yang diutarakan tersebut. Berisikan sebuah informasi, yang disampaikan oleh pembawa acar yang ingin memberi tahu kepada penonton bahwa ada pertanyaan yang masuk melalui email Islam Itu Indah.

(2) Salah satu penyebab seseorang susah untuk melanjutkan kehidupannya karena diganggu oleh masalalunya karena tidak bisa move on.

(Data 032.1.00225)

Data 032.1.00225 termasuk dalam tindak tutur lokusi pada jenis berita ditandai dengan kalimat " karena diganggu oleh masalalunya karena tidak bisa move on" 
kalimat tersebut termasuk ke dalam jenis tindak tutur lokusi hanya memberikan informasi bahwa banyak orang, yang tidak dapat melanjutkan hidupnya karena dibayangbayangi oleh masalalunya, tuturan tersebut hanya berisikan sebuah informasi bahwa salah satu penyebab seseorang susah untuk melanjutkan kehidupannya karena belum bisa move on, dan tuturan tersebut tidak memiliki tendensi apapun untuk melakukan sesuatu.

\section{b. Tindak tutur ilokusi}

Tindak tutur ilokusi adalah tindak tutur, yang memberikan sebuah informasi atau mengatakan sesuatu, dan dapat juga dipergunakan untuk melakukan suatu tindakan. Tindak tutur ilokusi terdapat beberapa jenis tindak tutur, di antaranya; tindak tutur asertif, direktif, ekspresif, komisif, dan deklaratif (Ibrahim abd. syukur, 1993: 11) Pada penulisan ini didapatkan macammacam tindak tutur ilokusi pada dakwah, yang disampaikan oleh Ustaz Muhammad Nur Maulana sebagai berikut:

1) Tindak tutur ilokusi asertif

Tindak tutur ilokusi asertif yakni tindak tutur, yang membahas mengenai sesuatu, yang mengikat kebenaran atas, yang dituturkannya. Pada tindak tutur ilokusi asertif meliki tujuh kelompok diantarnya menyatakan, menyanggah, menuntut, mempertahankan, mengakui, menyebut, dan menujukan. Pada tindak tutur ilokusi asertif pada dakwah Ustaz Muhammad Nur Maulana yakni didapatkan data sebagai berikut.

(26) Di dalam Al-Qur'an disebutkan ya bani Adam huzu zinatukum ingdakulli masjidiwwa kullu wasyrobu wala natusrifu. Innahu layu hibbulmus rifina. Wahai anak cucu Adam! pakailah pakaianmu, yang bagus pada setiap (memasuki) masjid, makan, dan minumlah tetapi jangan berlebihan, sungguh. Allah tidak menyukai orang, yang berlebih-lebihan.

(Data 05.2.0038)

Data 05.2.0038 tuturan tersebut merupakan tindak tutur ilokusi asertif karena pada tindak tutur tersebut sudah jelas mengikat kebenaran karena tuturan tersebut merupakan surat dalam ayat suci Al-Qur'an, dan Al-Qur'an merupakan pedoman umat Manusia, maka dari itu tuturan tersebut merupakan tuturan ilokusi asertif karena tuturan tersebut mengikat kebenaran atas apa, yang diucapkan.

2) Tindak tutur direktif

Tindak direktif adalah tindak tutur, yang dimaksudkan untuk menimbulkan efek dari sang penyimak, dalam tindak tutur direktif dikelompokkan menjadi tiga yakni meminta, memerintah, dan menyarankan. Dalam penulisan ini dapat dilihat pada data berikut.

(33) Mohon maaf wanita itu tulang rusuk bukan tulang punggung, dan wanita itu bukan tulang kepala, yang harus dijunjung, dan bukan tulang kaki, yang harus diinjak-injak. 
Data 04.2.0032 tuturan tersebut termasuk ke dalam tindak tutur ilokusi direktif "memohon" ditandai dengan kalimat "mohon maaf wanita itu tulang rusuk bukan tulang punggung" maksud dari tuturan tersebut adalah penutur meminta maaf kepada semua suami, yang memperlakukan istrinya tidak selayaknya sebagai tulang rusuk atau pendamping hidupnya.

3) Tindak tutur ilokusi ekspresif

Tindak tutur ilokusi ekspresif adalah tindak tutur, yang berfungsi untuk mengekspresikan, mengungkapkan, atau sikap psikologis lawan tutur sang pembicara. Pada penulisan ini didapat data ilokusi ekspresif pada dakwah yang disampaikan oleh Ustaz Muhammad Nur Maulana sebagai berikut.

(42) Assalamualaikum warahmatullahi wabarakatu.

(Data 04.2.0027)

Data 04.2.0027 termasuk ke dalam ilokusi ekspresif" mengucapkan salam " maksud dari tuturan ini yakni ketika ingin memulai ceramahnya Ustaz Maulana mengawalinya dengan kalimat salam yang bermaksud untuk mencontohkan akhlak Rasullah Sallahu Alaihi Salaam, di dalam sebuah hadis diterangkan bahwasanya dengan mengucapkan salam akan mempererat tali persaudaraan.

4) Tindak Tutur Ilokusi Komisif

Tindak tutur ilokusi komisif adalah tindak tutur, yang melibatkan pembicara pada tindakan, yang akan datang. Tindak tutur ilokusi komisif pada dakwah, yang disampaikan oleh Ustaz Muhammad Nur Maulana sebagai berikut.

(46) Barang siapa istri memuji suaminya maka ditambah uang belanjanya, dan barang siapa suami manjakan istrinya maka ditambah anaknya.

(Data 02.2.0015)

Data 02.2.0015 didapatkan tindak tutur ilokusi komisif yakni pada kalimat "barang siapa" itu termasuk ke dalam ke dalam tindak tutur ilokusi komisif menawarkan, dan memiliki makna agar suami istri saling mencintai, dan memuji satu sama lain.

5) Tindak Tutur Deklaratif

(50) jangan duduk dulu jamaah boleh maju ke depan.

(Data 07.2.004)

Data 07.2.0044 termasuk ke dalam tindak tutur ilokusi deklaratif yakni " larangan" ditandai dengan kalimat jangan duduk dulu tuturan tersebut berisakan sebuah larangan untuk jamaah untuk duduk terlebih dahulu karena di depan tempat duduk terdapat tempat duduk yang kosong.

c. Tindak tutur perlokusi

Tindak tutur perlokusi merupakan tindak tutur, yang diutarakan oleh seseorang, yang dapat mempengaruhi atau 
memberikan efek terhadap, yang mendengarnya (Ibrahim, 1993: 11). Penulisan ini didapatkan data tindak tutur perlokusi pada dakwah, yang disampaikan oleh Ustaz Muhammad Nur Maulana sebagai berikut.

(52) Jadi kalau ada suami, yang malas maka tugasnya istri adalah mengingatkannya karena suami itu sopirnya, istri adalah keneknya maka penumpangnya adalah anggota keluarganya.

(Data 011.3.0075)

(Data 011.3.0075) termasuk ke dalam tindak tutur perlokusi untuk melakukan sesuatu yakni ditandai dengan kalimat " tugas istri mengingatkannya" agar suami atau istri saling mengingatkan satu sama lain karena dalam keluarga harus saling mengingatkan, dan harus sejalan tujuan.

\section{Makna Tindak Tutur Dalam Dakwah Ustaz Muhamad Nur} Maulana

(Chaer, 2013: 78), makna, yang disampaikan oleh Ustaz Muhammad Nur Maulana sangatlah beragam sesuai dengan permasalahan, yang penulis angkat maka makna, yang dikaji adalah makna dari segi pragmatik yakni lokusi, ilokusi, dan perlokusi, pada penulisan ini hanya mengambil sampel sebanyak 68 makna tindak tutur, adapun rinciannya sebagai berikut.

a. Berbakti Anak terhadap Orang Tua

2) Sekarang banyak orang tua mengeluh yang mengeluh mempunyai anak perempuan dari pada anak laki-laki, benarkah Ustaz kelak nanti anak perempuan itu akan membawa orang tua ke surga atau ke neraka dan bagaimana yang harus anak-anak berbuat apa untuk orang tuanya.

(Data.08.1.0051)

Tuturan tersebut termasuk ke dalam tindak tutur lokusi berita, karena tuturan tersebut memberikan informasi mengenai orang tua yang mengeluh memiliki anak perempuan dari pada anak laki-laki. Makna dari tuturan tersebut yakni orang tua yang mengeluh memiliki anak perempuan ketimbang anak laki-laki sebenarnya jika kelak anak laki-lakinya menikah maka orang tua memiliki anak perempuan yaitu mantunya, tetapi menurutnya memiliki anak perempuan itu berat karena anak perempuan yang akan menentukan orang tua nantinya akan masuk ke dalam neraka atau ke dalam surga, kenapa seperti itu karena aurat yang dimiliki anak perempuan lebih banyak ketimbang aurat lakilaki, dan ketika orang tua mampu menjaga aurat anaknya dan kehormatan anaknya sampai anak tersebut mendapatkan pasangan maka orang tua tersebut kelak akan dibuatkan rumah di surganya, tetapi jika sebaliknya orang tua yang tidak dapat menjaga aurat anak perempuannya dan kehormatan anak perempuannya maka siksa api neraka sudah menunggu orang tua tersebut. Tugas anak perempuan sebenarnya lebih sulit ketimbang anak laki-laki maka dari itu sebagai anak seharusnya kita berbakti kepada orang tua dengan cara apa yakni dengan cara menjaga diri sendiri 
ketika anak menjaga diri sendiri maka anak tersebut sedang membuat rumah untuk orang tuanya di surga, dan sebalik ketika anak tidak menjaga diri dan auratnya maka anak tersebut sedang membuatkan siksaan api untuk kedua orang tua.

b. Keluarga

10) Mohon maaf jangan sampai berburuk sangka karena kadang kala berlebih-lebihan itu untuk menarik perhatian suaminya nggak apa-apa.

(Data 019.2.00134)

Tuturan tersebut termasuk ke dalam tindak tutur ilokusi "memohon maaf" karena pada tuturan tersebut ditandai dengan kalimat mohon maaf, penutur atau Ustaz Muhammad Nur Maulana mengatakan tuturan tersebut dengan tujuan memohon kepada suami yang di rumah untuk lebih memperhatikan istrinya. Makna yang terdapat dari tuturan yakni seorang istri yang berlebihan kepada suaminya kadang kala kurang mendapatkan perhatian bahkan bisa jadi tidak mendapatkan perhatian dari suaminya, makanya istri itu dibilang berlebihan karena ingin dimanja diperhatikan oleh suaminya. Istri adalah wanita yang memiliki hati yang lembut makanya tugas seorang suami ketika di rumah harus memanjakan istrinya, istri itu bukannya berlebihan tapi istri itu perlu kasih sayang dari pasangannya dan perhatian yang lebih dari pasangannya, karena aktivitasnya sehari-hari yang tak pernah usai dari bangun tidur sampai tidur lagi, itulah aktivitas seorang istri sehari selama sisa hidupnya, makanya wajar memiliki sikap berlebihan terhadap suaminya, makanya tugas suami sekali lagi sayangi istrinya agar istri tersebut tidak merasakan sendiri.

11) Suami ketika mengetahui istrinya durhaka ada tiga tindakan yang pertama menasihatinya, mengingatkannya, menuntun dan mendidiknya agar tidak durhaka.

(Data 01.2.006)

Tuturan tersebut termasuk ke dalam tindak tutur ilokusi menyebutkan karena ditandai dengan kalimat tiga tindakan yang harus dilakukan suami ketika istrinya durhaka. Makna yang terdapat dalam tindak tutur tersebut yakni tanggung jawab seorang suami yang mengetahui istrinya yang durhaka, maka dalam ajaran agama Islam ketika seorang suami mengetahui istrinya menjadi istri yang durhaka dan pembangkang atas apa yang sudah diperintahkan kepada istrinya maka suami tersebut memiliki tanggung jawab yang besar yakni mengingatkan atas apa yang dilakukan oleh istrinya itu adalah perbuatan yang salah dan tidak dibenarkan dalam ajaran agama Islam. Kelak suami istri tersebut akan bertemu di surganya yang Maha Kuasa ketika suami dan istri tersebut saling mengingatkan dalam hal-hal yang diridain Allah.

c. Rasa Syukur dan Rasa Sabar

33) Mohon izin tidak ada manusia yang tidak memiliki masalah. 
(Data 029.2.00205)

Tuturan tersebut termasuk ke dalam tindak tutur ilokusi direktif ditandai dengan kalimat " mohon izin" karena pada kalimat tersebut Ustaz Muhammad Nur Maulana meminta izin untuk menyampaikan tuturan tersebut. Makna dari tuturan tersebut bahwasanya tidak ada manusia yang tidak memiliki masalah dalam hidup pasti semuanya memiliki masalah masing-masing, tetapi bagaimana manusia tersebut menyikapi sebuah masalah yang sedang dihadapinya. Manusia yang bijak ketika ditimpa oleh sebuah masalah manusia tersebut bersyukur, karena dapat mengambil pembelajaran dari setiap masalah yang dihadapinya, Ingat Allah tidak akan memberikan cobaan melebihi batas kemampuan hamba-Nya.

34) Pa Ustaz Maulana bagaimana caranya agar kita menjadi orang yang selalu ingat dan tidak takut dengan ke matian.

(Data 035.1.00243)

Tuturan tersebut termasuk ke dalam tindak tutur lokusi dengan kalimat "caranya agar kita menjadi orang yang selalu ingat dan takut dengan ke matian" makna yang terdapat dalam tuturan tersebut yakni mempersiapkan diri untuk menghadapi ke matian, karena ke matian itu semua yang bernyawa akan mati, dan akan semua yang telah dilakukan di muka bumi ini kelak akan dimintai pertanggung jawaban, atas apa yang telah dilakukan semasa hidupnya, maka dari itu manusia mempersiapkan dirinya dengan cara selalu berkunjung ke tempat-tempat yang lebih sudah mendahului, dan selalu bersyukur atas apa yang diberikan oleh-Nya.

d. Kisah Nabi

49) Masalah ikan- ikan itu ada sinun, sinun itu adalah ikan, yang dimasuki oleh Nabi Yunus Alaihissallam. Satu rahmat, yang Allah berikan apa lagi semua, yang ada di laut.

(Data 017.1.00110)

Tuturan tersebut termasuk ke dalam tindak tutur lokusi. Tuturan tersebut memiliki makna kisah Nabi Yunus yang berada di dalam perut ikan, tetapi berkat rahmat yang Allah berikan Nabi Yunus tetap masih keadaan hidup di dalam perut ikan tersebut, dan nama ikan tersebut yakni ikan sinun, itu merupakan kemukjizatan yang diberikan oleh Allah untuk Nabi Yunus Alaihissallam.

e. Kegiatan Jual Beli

52) Kalau mau tahu sifat seseorang melakukan tiga perkara, yang pertama kau nginap di rumahnya, yang kedua mainlah bersamanya, dan yang ketiga berdaganglah dengannya.

(Data 018.2.00125)

Tuturan tersebut termasuk ke dalam tindak tutur ilokusi, dari tuturan tersebut memiliki makna yakni jika seseorang ingin mengetahui sifat orang lain maka tinggal atau menginap di rumahnya untuk mengetahui sifat dari orang tersebut, yang kedua mainlah dengan orang tersebut, dan yang terakhir yakni berdagang dengan orang tersebut. karena dalam perdagangan semua orang menginginkan dirinya tidak 
merugi, maka segala cara orang tersebut melakukan agar dagangan orang tersebut tidak rugi.

f. sunah dalam Islam

58) Alhamdulillah tepat 15 Rajab hari ini semoga kita mendapatkan berkah dibulan Rajab.

(Data 011.1.0067)

Data 011.1.0067 yakni termasuk ke dalam tindak tutur lokusi, karena ditandai dengan kalimat" tepat 15 Rajab hari ini" kalimat tersebut termasuk ke dalam tindak tutur lokusi, yakni berisakan sebuah informasi bahwa saat ini yakni tanggal 15 Rajab, bahwa ditanggal 15 Rajab kita akan mendapatkan keberkahan, yakni pada malam tersebut merupakan malam pertengahan atau malam ke 15 dibulan Syaban karena pada malam tersebut ada lima malam yang tidak akan ditolak doanya setiap hamba di dalamnya yakni malam pertama dibulan Rajab, malam Nisyfu' Syaban ( malam pertengahan atau malam ke-15 dibulan Syaban, malam Jumat, malam hari Raya Idul Fitri. Nabi Sallahu Alaihissallam bersabda " siapa yang menyambut malam pertama dibulan Rajab melakukan kegiatan keagamaan, seperti salat, puasa, membaca Al-Qur'an, dzikir dan lainlainya, maka ia berjiwa hidup, sekalipun umumnya manusia mati hatinya, dan Allah mencurahkan kebaikan (pikiran) bawah kepalanya, ia bersih dari dosa seperti baru lahir dari kandungan ibunya, dan ia diizinkan mensyafaati 70.000 ahli berdosa yang seharusnya di neraka. (lubil Al-Albab karya Maulana Tajul'Arifin/ Arajiyah). Bulan Syaban merupakan yang mulia, dan pada tanggal 15 Syaban disunnah untuk berdoa memohon ampunan kepada Allah. melakukan sunah yang lainnya.

g. Bekerja Keras

63) Kalau mau kaya milikilah malu, malu untuk mengemis, malu untuk meminta saya tidak cocok untuk mengemis dan meminta saya masih muda.

Data tuturan tersebut termasuk ke dalam tindak tutur ilokusi representatif menyatakan yakni ditandai dengan kalimat. Kalau mau kaya milikilah malu. Tuturan tersebut memiliki makna yakni seorang pemuda harus memiliki rasa malu untuk meminta kepada orang tua, karena sedari kecil sudah meminta kepada orang tua, setelah dewasa harusnya anak yang memberikan kepada orang tua, dan tanamkan dalam jiwa saya lebih baik tangan di atas dibandingkan tangan di bawah, artinya lebih baik saya memberikan apa yang saya miliki dibandingkan meminta belas kasihan dari orang lain.

h. Lisan

64) Hati-hati lidah itu tak bertulang dan semua yang tak bertulang berbahaya dosa.

Data tersebut termasuk ke dalam tindak tutur perlokusi yakni ditandai dengan kalimat hati-hati lidah itu tak bertulang, Karena tuturan tersebut memiliki makna mengenai hati-hati dalam berbicara, dan selalu menjaga lisannya karena 
tidak semua orang menyukai perkataan orang yang berbicara.

SIMPULAN

Berdasarkan hasil penelitian, dan pembahasan, yang disampaikan oleh penulis didapatkan hasil sebagai berikut. Tindak tutur, yang disampaikan oleh Ustaz Muhammad Nur Maulana sangat beragam dilihat dari segi penutur, yakni terdapat tindak tutur lokusi, ilokusi, dan perlokusi, jenis didapatkan jenis tindak tutur berita, tanya, asertif, direktif, representatif, deklaratif, komisif. Hasil penelitian didapat kan data sebanyak dua ratus empat puluh lima tindak tutur ilokusi, perlokusi, dan lokusi. Segi makna ceramah, yang disampaikan oleh Ustaz Muhammad Nur Maulana sangat beragam yakni mengenai; restu orang tua, wabah penyakit, istri yang durhaka, membahagiakan orang tua, dan sebagainya.

\section{DAFTAR PUSTAKA}

Banondari. R. (2015). Analisis Tindak Tutur Dalam Kegiatan Diskusi Pada Pembelajaran Berbicara Kelas X Sma $N 1$ Sewon. Skripsi Program Studi Pendidikan Bahasa dan Sastra Indonesia Fakultas Bahasa dan Seni Universitas Negeri Yogyakarta.

Chaer. A. (2013). Pengantar Semantik Bahasa Indonesia. Jakarta: Rineka Cipta.

Ibrahim. A. S. (1993). Kajian Tindak Tutur. Surabaya: Usaha Nasional.

Mahsun. (2005). Metode Penelitian Bahasa. Jakarta: Raja Grafindo Persada

Mahu. J. O. (2018). Pengembangan Buku Ajar Pragmatik Edukasional Terintegrasi Konteks Intralingual Dan Budaya Bagi Mahasiswa. Tesis.

Munir M \& Ilaihi. W. (2006). Menejemen Dakwah. Jakarta: Kencana Prenada Media Group.

Prasetyo, S. A. D. I. (2018). Analisis Tindak Tutur Direktif Pada Interaksi Guru Dan Siswa Dalam Pembelajaran Di Kelas V Sd Kanisius Sumber Magelang Tahun Ajaran 2017/2018.

Pusparini, N. F. (2016). Dalam Dakwah Kyai Haji Anwar Zahid ( Kajian Pragmatik) Skripsi.

Salafah. H. (N.D.). Tindak Tutur Ilokusi Dalam Ceramah Agama Tindak Tutur Ilokusi Dalam Ceramah Agama Kh A'ad Ainurus Salam.

Sudaryanto. (1993). Metode dan Aneka Teknik Analisis Bahasa: Pengantar
Penelitian Wahana Kebudayaan

Secara Linguistik. Yogyakarta:

Muhammadiyah University Press.

Sugiyono. (2015). Metode Penelitian Pendidikan Pendekatan Kuantitatif, Kualitatif, Dan R\&D. Bandung: Alfabeta.

Surastina. (2018). Pengantar Semantik \& Pragmatik. Yogyakarta: New Elmatera.

Wijana. I. D. P. (1996). Dasar-Dasar Pragmatik. Yogyakarta: Andi Offset.

Wijana, I. D. P. Dan R. (2013). Analisis Analisis Wacana Pragmatik Kajian Teori Dan Analisis. Surakarta: Yuma Pustika 